\title{
Evaluating The Internal Efficiency of General and Special Short Term Training Centers of Universities
}

\author{
Z. Rashidi and K. Danesh Fard
}

\begin{abstract}
- this study aims to investigate the assessment of internal efficiency of general and special short term training centers of universities by ranking the stages of in-service education (needs assessment, planning, implementation and evaluation) in the universities and raking the universities based on the adequacy of in-service education centers. The methodology of this study is of descriptive type and its objective is of applied type with methodology of surveyingdescriptive. Population includes all employees, members of faculty and administrative related to Islamic Azad University comprising 2600 people. To sample, there was used cluster sampling. The size of sample calculated about 324 people. In order for collecting the data, there was used author-made questionnaire. Collected data analyzed using $T$ Test and OneWay variance analysis and after L.S.D test by SPSS and Excel. Results indicated that there is significant difference between mean points of adequacy for observing the validation principles in different universities and implementation stage has most rate of adequacy. In this article has been presented the model for evaluation of internal sufficiency of in-service education centers of universities that it has attended to 5 basic factors that those are processes, participants, customers, plans and strategy and performance
\end{abstract}

Index Terms-Service Education, Needs Assessment, Planning, Implementation, Evaluation

\section{INTRODUCTION}

By complicating the businesses, there has been added to the importance of employees'

Training When businesses were simple, they could be easily learnt with technical deformations had slightly influenced on them; therefore, it was not necessary to increase or change their skills. But accelerated deformations, specially occurred

During last decades in different communities increasingly pressurized on the organizations to adapt the types of products and services produced, how they produced and supplied, type of jobs

Required and type of skills needed for conducting such businesses. In a fast deforming community,

training the employees not only is proper but also an activity by which any organization must consider some sources for it to be provided always with efficient and informed human resources [5].

It is noteworthy two main points: first, one needs to differentiate between two concepts of in-service training and

Manuscript received August1, 2010; revised September 21, 2011

Zolfaghar Rashidi is faculty member \& of Islamic Azad University, Zarandiye Branch, Tehran-Iran .(e-mail: hr hrashidi@yahoo.com) (Tel.: +98 21 22542664-22640442, Fax: +98 21 22640427-22558700)

Karamollah Danesh Fard is Assistance Professor \& of Islamic Azad, University, Science and Research Branch, Tehran-Iran. (e-mail: cdaneshfard@yahoo.com). (Tel.: +98 $21 \quad$ 22543733, Fax: +98 21 22558700- 22614613) development or nurturing the employees. This is because developing the employees is a concept more extended and comprehensive than in-service training, on one side and that is any activity or systematic attempt aiming to develop the personnel; while in-service training is a more limited concept and comprising those trainings provided for improvement of personnel performance and consequently increased organizational performance [10]. Therefore, employees' development plans include in-service training plans, but in-service training is only a subset of employees' development plans [10]. Occasionally, managers select among contrary objectives encountered by organization, one or several cases and employ organizational possibilities to achieve those objectives. What helps to managers to select special objectives among contrary objectives is the approach of their efficiency [16]. While defining the efficiency as the rate of achieving the goals in short term and long term, the organizational performance reflecting the efficient approaches of managers [18]. Managers' approaches are the same as their view to the organization and their efficiency approaches also indicates their view to the organizational efficiency [21]. They direct the organization towards where they think approaching to that destination may increase the organizational efficiency [21]. The approaches of managers influence on determining the goals, human resources of organization and how to select and direct them, methods, processes, mechanisms and how conducting them, financial resources and how to determine and using them [14].

Assessment is one the most important mechanisms of performance management in producing and developing the quality in the organization. Quality improvement indeed requires quality assessment and this can be seen in all organizations, whether industrial, commercial and training organizations [6].

One of the models used for improving the quality in higher education from long ago was validation model. For validation, there are two general and specific definitions, its general definition in the Webster Dictionary includes: allocating the validity to a set with standards. This validation is conducted by regional communities [18]. For its specific meaning in the organized knowledge of higher education, the validation means the quality control process and evaluating the plan progress of an institute or progress efficiency based on pre-defined and standard measures. In higher education dictionary, Aldenlam considers the validation as a quality control process and reliability in the higher education and adds: by validation, one can deal with reviewing, assessing or both as well as inspecting the institute and its plans for ensuring the achievement of minimum acceptable standards. Some other authorities (higher education institutes) believe that university validation is principally related to the progress of training quality of region as well as general quality of regional 
institutes and their conformity with standards [1]. Validation is indeed making the in-service training centers responsible as well as quality control process of institutes and their plan in order for ensuring the achievement of minimum acceptable and determined standards and indicators. One can divide the validation model into two general parts: 1Internal evaluation 2-External evaluation

Internal evaluation is a process in which in-service training centre of universities considerably judge about their performance and determine what their situation in their current thoughts for quality is. It means whether Human Resources Training Centre of university X observe measures such as needs assessment, implementation and evaluation in its plans? And finally, we can use the results as data for planning to improve the future activities. Internal evaluation is not only responsible for analysis of strengths and weakness as well as recommendations, but also for improving the problems and implementing the solutions. By collecting the data, analyzing and its feedback, internal evaluation supports the management decisions. On the other hand, internal evaluation is a process by which system members evaluate the system quality of different views. It means, involved people of in-service training canters find the strengths, weaknesses, opportunities and threats of training centres, then, by cooperation plan to improve the quality. The objectives of internal evaluation include:

1) Development of evaluation culture

2) Making a quality assurance system in the universities and making the incentive among members of faculty for making the activities and their duties effectiveness.

3) Making the needed bed for validation and assigning the authorities as well as decentralization of activities of higher education system for fulfilling the assigned objectives and mission [13].

External evaluation: it is the process of quality confirmation using homogenous external groups. On the other hand, in external evaluation, we aim to examine the validation indices considered in this study for in-service training centers of Islamic Azad University. For example, we examine the situation of validation from plans in the inservice training canter $\mathrm{X}$ with training centre $\mathrm{Y}$ by which, we can rank the in-service training centers of Islamic Azad University that is the main objective of this study.

According to above mentioned, and based on studies, this question can be asked by researchers that: have in-service training centers of Islamic Azad University qualified for holding the in-service courses? So, this study aims to answer this question.

When entering to the organization employees become familiar with priorities and strategies of organization by explanatory and social acceptance plans by which while reducing the stress when entering to the new environment and accepting the new responsibilities, they can fast adapt themselves with objectives of organization as well as internal processes and methods of performance evaluation and generally expectations of management and organization [15].

Organizationally, in-service training is considered that kind of training that can be conducted after employing the employee in the organization. According to this fact, there provided different definitions for in-service training of employees that will be defined later. In-service training aims to make more production, increased efficiency in the current job and attaining better conditions for achieving higher positions [1]. By above mentioned, one can conclude that inservice training is indeed defined as below:

1) It is conducted after employing the employee in the institute or organization

2) Such kind of training aims to prepare people to optimally executing their job commitments.

3) Such trainings mainly provided in three main factors including knowledge, skills and attitudes (KSAs).

4) Main direction of such trainings is jobs or occupied duties [10].

The process of training is based on stages (needs assessment, planning, conduction and evaluation) might be influenced by factors such as support and commitment of superior management, technological progresses, environmental complications, learning styles and other functions of human resources and it albeit might influence on them [19]. To achieve their training goals, organizations use methods such as case study, behavioral modeling, playing roles, managerial plays, workshop training... [7]. such methods are conducted by the programs of organization itself or by universities and faculties performed in one's presence or not.

Training planning includes regularly applying the analysis methods for any component of mentioned training system and aiming to establish an efficient training system [11]. Training planning process in different organizations includes: (1) recognizing the training needs; (2) preparing the objectives of training plans; (3) determining the sources needed for training plan; (4) conducting the training plan (5) evaluating the training plan [10].

After the stage of needs assessment and preparing the training plans, the next stage is in-service training plan. Conducting this plan means the process of performing a determined plan or design [17]. Some specialists believe that the way of conducting the plan is more important than preparing it; because until a plan has not been implemented, it may not provide the organization and employees with a given result, on one side, and best plans can make improper results by faulty implementations, on the other side, while a defective plan might be more efficient if implemented properly [11].

The most important question in the field of in-service training is that: what is the situation of evaluating the inservice courses in the planning process and in which stage it can be conducted? For answering this fundamental question, there have been discussed various models and views and they can generally classified into two following models.

Traditional perception from the situation of evaluation in the planning for training courses: in traditional perception, now has been abolished, the evaluation is conducted at the end of in-service training, i.e. after preparing and implementing the training courses [22]. In such situation, the main objective of evaluation included recognizing the effect of training courses after the end of training process and to attain such result, it was more used poling and reviewing the views of participants.

New perception from situation of evaluation in the planning for training courses: evaluation in new perception 
is conducted during any different stage of in-service training process. Evaluation in the stage of needs assessment indicates the recognition and determination of training priorities based on real problems. Evaluation in the stage of preparing and conducting the program indicates recognizing the deviations and assessment of proper movement in the predefined route (formative evaluation) and finally evaluation at the end of course indicates explaining and judgment for efficiency and rate of training courses success (final evaluation) and following-up evaluation is conducted times after the end of course for assessing the real results of plan.

\section{LITERATURE REVIEW}

In the field of validation from universities and higher education centers there have been conducted various activities through the world and its result is making a ranking system for international universities as well as publishing the list of 500 prominent universities as an annual report. Some countries such as USA, France, Germany, UK, Australia, Japan and South Korea,... had studied in this field that resulted in making the validation systems and ranking in such countries and now, in order for increasing the training services level in the universities of these countries, there are used different tools and techniques. In our country, Iran, continuously evaluating the higher education plans is in its novelty but during two recent decades, there are several $\mathrm{PhD}$ theses in the field of validation and there are only a few patchwork activities about evaluating the performance through the organizations related to higher education. Of course, it must be mentioned that any activities in this field have not conducted by the view to evaluating the in-service training centers and therefore, the subject of this study is new.

Baghaei, Shiva conducted a study called "studying and designing a proper evaluation model for validating the high schools of average training new system. This study aimed to provide a proper model for evaluating the new system high schools based on standards prepared by author. This study conducted in two stages (a) designing a model (b) launching the related model. In the first stage, using knowledge about the problem, there was dealt with reviewing the evaluation model; among them there was chosen one as a proper model. This model is validation model and standards needed for using this study prepared by enjoying from the views of different experts and training managers[4].

There was also conducted a study by Mirza Mohammadi called "internal evaluation of training quality in the ministry of power". After determining the factors, this author dealt with determining the criteria related to any on such factors and in the next step, there have been defined and prepared indices related to each factor and thus, the proper situation has been determined according to (a) training objectives and (b) expectations of members of faculty. After this stage until data collection and using interview and questionnaires, it has indicated its status quo and comparing it with suitable situation, found the suitability of status quo and judged about it[12].

In his $\mathrm{PhD}$ thesis, called "A Model for Evaluating the Universities and Higher Education Institutes of Country",
Pasargady tried to practically launch the validation model. This study decides to respond two main questions:

1) Which model can be discussed for higher education of country in the field of validation?

2) Has the proposed model a national validity?

3) To determine the evaluating factors, author focused on the factors used for validation of higher education centers in different countries through the world. Two general classes were considered for determining the indicators: 1- Structural indicators 2-Efficiency indicators[19].

Results from study by Sheikh Al-Eslami called "Studying and Designing a Proper Evaluation Model for Evaluating the Training Groups of Persian Literature and Language in the Country's Universities" indicates that internal evaluation is necessary for interesting the members of faculty and attracting their cooperation for improving the quality of training activities of mentioned groups[22].

\section{STUDY QUESTIONS}

Main Question: Have the in-service training centers of Islamic Azad University of district 10, the needed validity for needs assessment, planning, implementing and evaluating the in-service training courses?

Side Question:

1) Have the in-service training centers of Islamic Azad University of district 10 , the needed validity for needs assessment the in-service training courses?

2) Have the in-service training centers of Islamic Azad University of district 10 , the needed validity for training planning?

3) Have the in-service training centers of Islamic Azad University of district 10 , the needed validity for implementation?

4) Have the in-service training centers of Islamic Azad University of district 10 , the needed validity for evaluating the efficiency?

5) Is there any significant difference between validity of inservice training centers of Islamic Azad University of district 10 based on needs assessment, planning, implementation, and evaluation?

\section{OBJeCtives OF STUdy}

General Objective: Studying the evaluation of internal adequacy of general and specific short term training centers of Islamic Azad University, by which, the training centers are validated and training stages ranked

Side Objectives:

1) Comparing and evaluating the validity of in-service training centers of Islamic Azad University of district 10 based on (training needs assessment, planning, implementation and evaluation);

2) Ranking the training stages (training needs assessment, planning, implementation, evaluation) in any Islamic Azad University of district 10;

3) Evaluation and ranking the validity of Human Resources training Centers of Islamic Azad University, district 10; 
4) Recognizing the strengths and weaknesses of Human Resources training Centers of Islamic Azad University, district 10;

\section{Methodology}

This study objectively is of applied type and based on collecting the information is of descriptive- surveying type. Population includes all employees, members of faculty and managers of units in district 10 of Islamic Azad University comprising 2600 people.

There was used cluster sampling to select statistical sample classified according to three groups (participants in the course, executive managers of the courses and teachers of the training courses). But for choosing the number of people for receiving the surveys, there was used accidental sampling. The number of sample for participants includes 209 for teachers include 70 and for executive managers include 10 people.

Questionnaire was considered as a data collection tool, and in this study there was used three types of questionnaire for three groups (participants, course teachers and executive managements) prepared by Likert spectrum. The validity of this questionnaire was verified by apparent validity and using the view of experts and researchers and its reliability verified by calculating the Krunbach alpha in 0.87 . Krunbach alpha also was obtained about 0.75 for training needs assessment, 0.77 for planning, 0.78 for implementation and 0.80 for training evaluation. Descriptive statistics used for grouping the groups of tests and inferential statistics.

\section{DATA ANALYSIS}

After collecting and classifying the data, there were used two methods, descriptive and inferential statistics for data analysis. Descriptive statistics has been used for classifying the test group based on their different traits, describing the properties of population from frequency distribution tables, frequency percentage, percentage, mean, median, mode, histogram and bar charts, min and max. By inferential statistics, the t-tests and one-way variance analysis test and L.S.D. past-test were used based on hypotheses for using them. The collected data extracted from questionnaire and related answers were analyzed using mentioned method by SPSS and Excel.

TABLE 1: EVALUATING THE ADEQUACY IN VALIDATION PRINCIPLES
\begin{tabular}{|c|c|c|c|c|}
\hline $\begin{array}{c}\text { Adequacy } \\
\text { in } \\
\text { validation } \\
\text { principles }\end{array}$ & $\mathrm{n}$ & Mean & SD & $\begin{array}{c}\text { SD from } \\
\text { Mean }\end{array}$ \\
\cline { 2 - 5 } & 190 & 100.01 & 12.13 & 0.88 \\
\hline
\end{tabular}

\section{RESULTS}

Question: Have in-service training centers of universities related to Islamic Azad University qualified for needs assessment, planning, implementation and evaluation of inservice training courses?

Table 2 indicates that $t$ calculated (31.82) with freedom degree of 189 and $\alpha$ value 0.05 is greater than t critical. Therefore, H0 indicating no difference between mean of scores of tests (100) with population mean (72) is rejected and by confidence $95 \%$, one can state that there is significant relation between sample mean and community mean, such that the sample mean is higher than population mean. Therefore, the situation of studied population based on observing the validation principle is higher than the average.

TABLE 2: T-STUDENT TEST

\begin{tabular}{|c|c|c|c|c|c|c|}
\hline \multicolumn{7}{|c|}{ Test value $=72$} \\
\hline \multirow{3}{*}{$\begin{array}{l}\text { Adequacy } \\
\text { in } \\
\text { validation } \\
\text { principles }\end{array}$} & \multirow[b]{2}{*}{ t value } & \multirow{2}{*}{$\begin{array}{c}\text { Freedo } \\
\mathrm{m} \\
\text { degree }\end{array}$} & \multirow{2}{*}{$\begin{array}{c}\text { Signifi } \\
\text { cance } \\
\text { level }\end{array}$} & \multirow[b]{2}{*}{$\begin{array}{c}\text { Mean } \\
\text { difference }\end{array}$} & \multicolumn{2}{|c|}{$\begin{array}{c}\text { Confidence level } \\
0.95\end{array}$} \\
\hline & & & & & $\begin{array}{c}\text { Lower } \\
\text { limit }\end{array}$ & $\begin{array}{c}\text { Upp } \\
\text { er } \\
\text { limit }\end{array}$ \\
\hline & 31.8 & 189 & 0.0 & 28.01 & 26.27 & $\begin{array}{c}29.7 \\
5\end{array}$ \\
\hline
\end{tabular}

\section{Side Questions}

1- Have the in-service training centers of Islamic Azad University of district 10 , the needed validity for needs assessment the in-service training courses?

2- Have the in-service training centers of Islamic Azad University of district 10 , the needed validity for training planning?

3- Have the in-service training centers of Islamic Azad University of district 10 , the needed validity for implementation?

4- Have the in-service training centers of Islamic Azad University of district 10 , the needed validity for evaluating the efficiency?

5- Is there any significant difference between validity of in-service training centers of Islamic Azad University of district 10 based on needs assessment, planning, implementation, and evaluation?

Table 3 indicates variance analysis (ANOVA) for studying the situation of training stages (needs assessment, planning, implementation and evaluation) among universities, a subsidiary of Islamic Azad University and briefly described as below.

TABLE 3- VARIANCE ANALYSIS (ANOVAs) FOR STUDYING THE Situation Of Training Stages BETWEen UNIVERSITIES A SUbSIDIARY OF ISLAMIC AZAD UNIVERSITY.

\begin{tabular}{|c|c|c|c|c|c|c|}
\hline $\begin{array}{c}\text { Train } \\
\text { ing } \\
\text { stage } \\
\text { s }\end{array}$ & $\begin{array}{l}\text { Resources } \\
\text { for change }\end{array}$ & $\begin{array}{l}\text { Sum of } \\
\text { squares }\end{array}$ & df & $\begin{array}{c}\text { Mean } \\
\text { of } \\
\text { square } \\
\text { s }\end{array}$ & $\mathrm{F}$ & $\begin{array}{c}\text { Signifi } \\
\text { cant } \\
\text { level }\end{array}$ \\
\hline \multirow{3}{*}{$\begin{array}{c}\text { Need } \\
\text { s } \\
\text { asses } \\
\text { smen } \\
\mathrm{t}\end{array}$} & Inter-group & 178.8 & 9 & 19.8 & 2.7 & 0.004 \\
\hline & Intra-group & 1420.2 & 198 & 7.1 & & \\
\hline & Total & 1599.1 & 207 & & & \\
\hline \multirow{3}{*}{$\begin{array}{c}\text { Plann } \\
\text { ing }\end{array}$} & Inter-group & 269.8 & 9 & 29.9 & 2.7 & 0.005 \\
\hline & Intra-group & 20445.3 & 189 & & & \\
\hline & Total & 2315.2 & 198 & & & \\
\hline \multirow{3}{*}{$\begin{array}{l}\text { Impl } \\
\text { emen } \\
\text { tation }\end{array}$} & Inter-group & 452.4 & 9 & 50.2 & 2.6 & 0.006 \\
\hline & Intra-group & 554.6 & 188 & 18.9 & & \\
\hline & Total & 4007.0 & 197 & & & \\
\hline \multirow{3}{*}{$\begin{array}{c}\text { Eval } \\
\text { uatio } \\
n\end{array}$} & Inter-group & 308.3 & 9 & 34.2 & 2.6 & 0.007 \\
\hline & Intra-group & 2528.8 & 195 & 12.9 & & \\
\hline & Total & 2837.2 & 204 & & & \\
\hline
\end{tabular}

According to calculated F- 2.77 for needs assessment, 2.771, for planning, 2.659 for implementation, 2.642 for 
evaluation- and significant level- 0.004 for needs assessment, 0.005 for planning, 0.006 for implementation, 0.007 for evaluation-, one can conclude that there is significant difference between mean score of training stages separated based on different universities.

Table 3 indicates variance analysis (ANOVA) for studying the situation of training stages (needs assessment, planning, implementation and evaluation) among universities, a subsidiary of Islamic Azad University and briefly described as below.

According to calculated F- 2.77 for needs assessment, 2.771, for planning, 2.659 for implementation, 2.642 for evaluation- and significant level- 0.004 for needs assessment, 0.005 for planning, 0.006 for implementation, 0.007 for evaluation-, one can conclude that there is significant difference between mean score of training stages separated based on different universities.

For collecting the information needed for data analysis in the questionnaire, in the needs assessment stage there has been tried to: training courses are related to new duties assigned to employees, courses provide the job requirements of employees; courses held based on the content of job description and conditions for job obtaining of employees; the scientific level of participants is proportional with the level of training course; the views of training managers will be considered when preparing the training courses. In the planning stage, for training planning there has been attempted to consider followings: presence of welfare possibilities for trainers and participants, prepared lesson schedule, information sharing for booklet of lesson plan and contents as well as its context before holding the course, adaptation of lesson plan with workshop objectives, relation of workshop context with employees duties, presence of full databank from trainers and participants as well as data sharing system for calendar of annual training courses and in the implementation stage there has been tried to: holding the courses according to time schedule, presence of proper light and temperature in the place of holding the workshop, giving the book and booklets to the participants and accessing to the internet, issuing the certificate for participants, presence of educational aid instruments in the workshop, orderly presence of course management in the workshop, documenting the training courses and accessing to the annual calendar of courses and in the evaluation stage it has been tried to: accessing to the predefined objectives in the lesson plan, effect of training plans for improving the employees performance, participants satisfaction of presence in the workshop, how training plan could percept the employees of their duties, improving the view of employees to their job as well as assessing the participants at the end of the course.

According to the calculated F (2.906) and significant level (0.003), one can judge that there is significant difference between the mean of adequacy score for observing the four fold principles separated in universities, subsidiary of Islamic Azad University.

Therefore, based on the adequacy score for observing the four fold principles of training, Shahrood University has the first score, Gorgan and Minoodash universities have the second and third scores respectively.

TABLE 4- VARIANCE ANALySis (ANOVAs) For ADEQUACy IN OBSERVING THE Four Fold PRINCIPLES SEPARATED BASED ON UNIVERSITIES For THEIR RANKING

\begin{tabular}{|c|c|c|c|c|c|c|}
\hline $\begin{array}{c}\text { Training } \\
\text { stages }\end{array}$ & $\begin{array}{l}\text { Resour } \\
\text { ces for } \\
\text { change }\end{array}$ & $\begin{array}{l}\text { Sum of } \\
\text { squares }\end{array}$ & $\begin{array}{c}\text { Freedo } \\
\mathrm{m} \\
\text { degree }\end{array}$ & $\begin{array}{c}\text { Mean of } \\
\text { squares }\end{array}$ & $\mathrm{F}$ & Significant level \\
\hline \multirow{3}{*}{$\begin{array}{c}\text { Adequacy } \\
\text { situation }\end{array}$} & $\begin{array}{l}\text { Inter- } \\
\text { group }\end{array}$ & 3531.8 & 9 & 392.4 & $\begin{array}{l}2 \\
. \\
9 \\
0 \\
6\end{array}$ & 0.003 \\
\hline & $\begin{array}{l}\text { Intra- } \\
\text { group }\end{array}$ & $\begin{array}{c}24307 . \\
0 \\
\end{array}$ & 180 & 135.0 & & \\
\hline & Total & $\begin{array}{c}27838 \\
9\end{array}$ & 189 & & & \\
\hline
\end{tabular}

the courses.

For assessing the internal evaluation, there was used

\section{DISCUSSION AND CONCLUSION}

This study aims to evaluate the internal adequacy of general and special short term training centers of Islamic Azad University. Therefore, after studying the theoretical basic and in-service training stages as recognized in four stages and discussed in four micro scales, they were investigated in the framework of a question. By such study, the adequacy in observing the four fold principles of training stages (needs assessment, planning, implementation and evaluation) have been verified, i.e. in-service training centers of universities enjoy needed adequacy for holding means comparing test. Internal evaluation is a process in which in-service training centers of units have considerable judgments for their performance and determine what the situation of quality in current thoughts is: results include:

By comparing the training stages in Azadshahr unit, using means comparing test, it was determined that: the stage of "needs assessment" in this unit based on possessing the maximum mean ranked in first and in other units it ranked in fourth class.

Comparing the training stages in Azadshahr, BandarGaz, Damghan, Semnan, Shahrood, AliAbad, Garmsar, Minoodasht units, using means comparing test, it was 
determined that "planning' stage in these units based on possessing maximum mean ranked in first, and in Gorgan and Gonbad, ranked in fourth class.

Comparing the training stages in Islamic Azad Universities of district 10, using means comparing test, it was determined that the "implementation" stage in all universities of the district, based on possessing the maximum mean ranked in first class.

Comparing the training stages in BandareGaz, Damghan, Semnan, Shahrood, Aliabad, Garmsar, Minoodasht units, using means comparing test, it was determined that the "Evaluation" stage in these units, based on possessing maximum mean ranked in second, and in Gorgan and Gonbad units, ranked in third and in Azadshahr unit rank in fourth class.

In external evaluation, there was used t-test and one-way variance analysis to study the validation indicators in inservice training centers of universities of district 10 .

The situation of needs assessment based on separated Islamic Azad Universities of district 10: according to calculated F (2.77) and significance level (0.004), one may judge that there is significant difference between mean of needs assessment score between universities of district 10 . Therefore, based on needs assessment, Shahrood university ranked in first, Azadshahr, Garmsar, Aliabad, Semnan, Damghan, Grgan, Minodasht ranked in the next levels respectively.

The situation of planning based on separated Islamic Azad Universities of district 10: according to calculated F (2.77) and significance level (0.005), one may judge that there is significant difference between mean of planning score between universities of district 10. Therefore, based on planning, Shahrood University ranked in first, and Gorgan and Minoodasht universities ranked in second and third levels, respectively.

The situation of implementation based on separated Islamic Azad Universities of district 10: according to calculated F (2.659) and significance level (0.006), one may judge that there is significant difference between mean of implementation score between universities of district 10 . Therefore, based on implementation, Gorgan University ranked in first, and Minoodasht and Shahrood universities ranked in second and third levels, respectively.

The situation of evaluation based on separated Islamic Azad Universities of district 10: according to calculated F (2.64) and significance level (0.007), one may judge that there is significant difference between mean of evaluation score between universities of district 10. Therefore, based on implementation, Shahrood University ranked in first, and Gorgan and Minoodasht universities ranked in second and third levels, respectively.

It Results of this study are adapted with the results of other internal researchers such as Baghaei, Mirza Mohamadi, Sheykh Al-Eslami [8] [12] [2].

As mentioned above, it can be concluded that the results of this study indicate that in-service training centers of universities, subsidiary of Islamic Azad University enjoy the needed adequacy and validity for managing the in-service training courses and there is significant difference between the validity of in-service training centers of universities based on the stages of training (needs assessment, planning, implementation and evaluation). When comparing the training stages also, the implementation and needs assessment stage allocated the highest and lowest ranks among universities, respectively.

Providing the internal adequacy model for in-service training centers

It is proposed that: in-service training system must be adapted to organizational systems and evaluation must be conducted according to following factors:

Internal adequacy: in the internal adequacy there has been dealt with evaluating four stages of in-service training including: needs assessment, planning, implementation and evaluation.

If there is attended to the evaluation of internal adequacy of training center by systemic approach, there will be considered several main criteria in the evaluation.

Such adequacy evaluation system of course influenced by its inputs including: customer's need, need to change, need to new skills, and new duties. Naturally, such system can has effects such as: recognizing the weaknesses and strengths, evaluating the adequacy of training courses, evaluating the adequacy of training plans, evaluating the adequacy of training organizations.

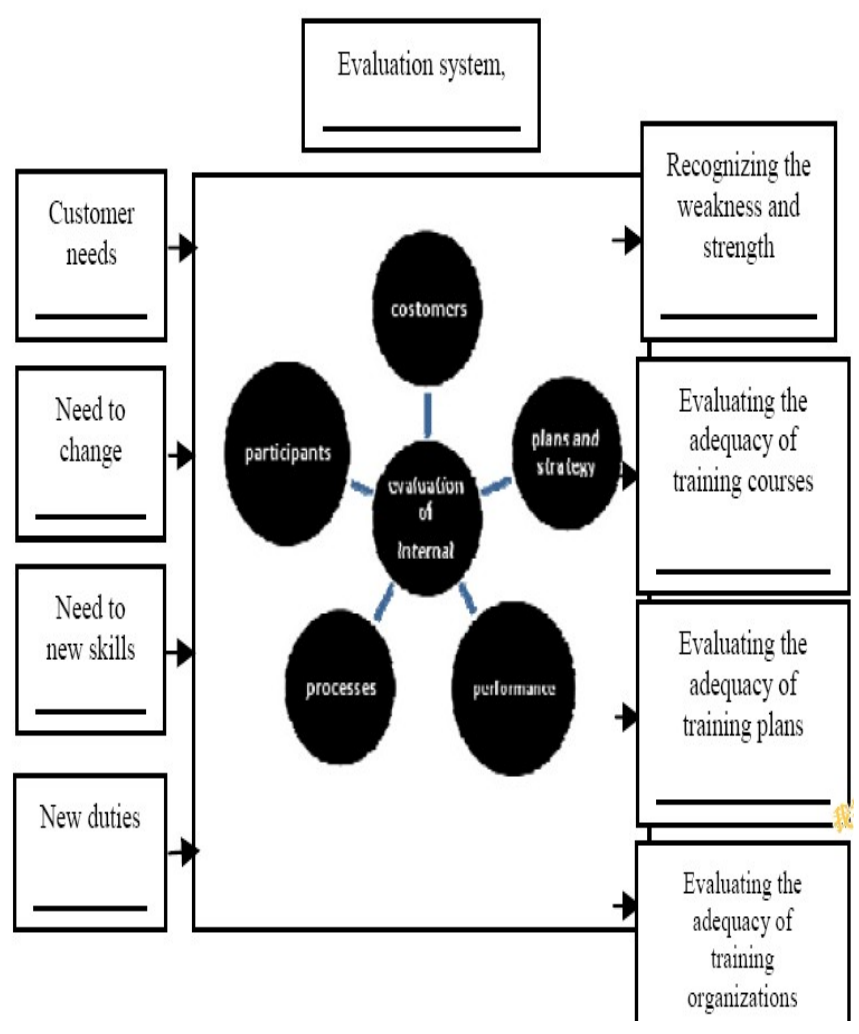

Fig.1.Model for internal adequacy of in-service training centers

\section{RECOMMENDATIONS}

- Needs assessment, that is one of the main stages in the training, needs to be more attended to fulfill the plans and implementation based on this principle and is seen by applied view. Of course, besides this principle, it is needed to pay attention to other principles as well.

- People, who assigned as courses managers, must be preferably enjoyed higher education and experience. It seems that if managers assigned from members of faculty, 
their performance may be better. It is also needed to prepare applied courses for promoting the performance of courses managers.

- Creating in-service training validation center in university regions for controlling and periodically evaluating the in-service training centers.

- In-service training courses based on the adequacy of university centers may be referred to for holding them.

- Data sharing to courses managers in the field of timely in-service activities by which more people can be covered by such courses; because scientifically developing the university requires timely training of employees and members of faculty.

- Promoting the plans and in-service courses requires increased spirit of group cooperation of employees and members of faculty and fulfilling this case needs coordinated management by which it can be developed the cooperation spirit and reciprocal trust between employees and members of board and managers.

\section{REFERENCES}

[1] C. Adelman. The Encyclopedia of Higher Education, Analytical Perspectives. 1992, Vol.2.pp:1314-13150

[2] H. Abtahi. Training and improving HR, studies and training planning institute of development and renovation organization of Iranian. Industry press,2nd edition, 1996.

[3] M. Abbas Zadeghan, J. Tork Zadeh. Training needs assessment in the organizations. Tehran, Enteshar Cooperative, 2002.

[4] S. Baghaei. Studying and planning for the suitable evaluation model for validation in new system high schools. Master thesis, 1995.

[5] R. Daft L. Understanding the Theory and Design of Organizations. Tenth Edition, South- Westerw Cerigage Learning, 2010

[6] N. Dam. The Business Results of Strategic On boarding. Chief Learning Officer, June, 2007.

[7] S. Dolan, R.S.Shouler. Employees Affairs and HR Management. Translated by Mohammad Ali Toosi and Mohammad Saebi, Public Management Training Center, Tehran, 1996.

[8] K. Fathi Vajargah. Planning for in-service training of employees, Tehran: Samt Press, 2nd edition, 2005.

[9] A. Field. Do Your Stars See a Reason to Stay? Harvard Management Update 13 April, 2008

[10] M. Fullan. Curriculum Implementation, in A. Lewy(Ed), International Encyclopedia Of Curriculum. Pergamum Press, 1991.

[11] A. Khorshidi. Providing a theoretical framework for performance indices related to promotion of quality of Iranian higher education. PhD thesis. Tehran: Islamic Azad University, Science and Research Unit, 1997.
[12] M. Mohammadi. Studying and designing the proper model for internal evaluation of training quality of Ministry of Power. Thesis for Master, field of training planning, 1997.

[13] R. Mohammadi. Internal evaluation of quality of mathematics training group (applied), of Amirkabir Industrial University. Master thesis, Faculty of Psychology and Education Science of Tehran University, 2002.

[14] S. Moir. Segmenting Benefits to Suit Staff is Beneficial. Employee Benefits. Feb, 2008.

[15] R.W.Mondy. Human Resource Management. Eleventh Edition, Pearson, 2010.

[16] B. Morris. Why Good Hires Go Bad. Profit, 24 June, 2005.

[17] C. Ostroff, S.N. Cheri. Configurations of Organizational Effectiveness and Efficiency. Academy of Management Journal (36), 1993.

[18] M. Pazargadi. Validation in Higher Education. Tehran, Sabah Press, 1999.

[19] M. Pazargadi. Training management a model for validating the universities and higher education institutes (in public and non-public sector). PhD thesis, 1998.

[20] M. Reeves. Evaluation Of Training. London, the Industrial Society publishing, 1998.

[21] R. Rodriguez. Learning, Impact on talent Flow. Chief Learning Officer (7 April), 2008.

[22] R. Sheykh Al-Eslami. Studying and designing the models of peoper evaluation for validating the Persian Language and Literature Training Groups in country's universities. Thesis for master of training planning, educational science faculty of Isfahan University, 1998.

[23] I. Soltani. Performance Management and its Executive Mechanisms in quality production. Quarterly of management studies. 2004, Nos. $41-42$.

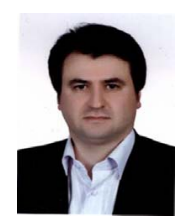

Zolfaghar rashidi,, master of art of educational administration from Iran. He has 7years experiences in planning and training of human force, and he is faculty member of islamic Islamic azad university .he possesses research articles that have been issued in nationally And so presenting articles in national and internationa conferences.

Address: Islamic Azad University, P.O.Box: 19585/466./ No.3, 9th Neyestan, Pasdaran Ave. TEHRAN/ I.R. IRAN

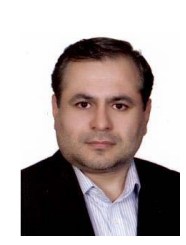

Karamollah Danesh Fard., master of art and $(\mathrm{PhD})$ profession of human resources management from Iran. He has 20 years experiences in planning and training of human force and so improvement and human resources management in university, industry and commerce. $\mathrm{He}$ possesses more than 20 research articles that have been issued in nationally and so presenting articles in national and international conferences. He is faculty member of Islamic Azad University

Address: Islamic Azad University, P.O.Box: 19585/466./ No.3,9th

Neyestan, Pasdaran Ave. TEHRAN/ I.R. IRAN 